\title{
Klinik Örneklerden İzole Edilen Enterococcus faecium ve Enterococcus faecalis İzolatlarının Antibiyotik Direnci ve Virülans Faktörlerinin Araştırılması
}

\section{Investigation of Antibiotic Resistance and Virulence Factors of Enterococcus faecium and Enterococcus faecalis Strains Isolated from Clinical Samples}

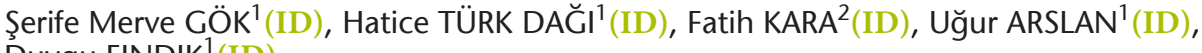 \\ Duygu FINDIK! 1 (ID)! \\ 1 Selçuk Üniversitesi Tıp Fakültesi, Tıbbi Mikrobiyoloji Anabilim Dalı, Konya. \\ 1 Selcuk University Faculty of Medicine, Department of Medical Microbiology, Konya, Turkey. \\ ${ }^{2}$ Selçuk Üniversitesi Tıp Fakültesi, Halk Sağlığı Anabilim Dalı, Konya. \\ 2 Selcuk University Faculty of Medicine, Department of Public Health, Konya, Turkey
}

* Bu çalışma, Selçuk Üniversitesi Bilimsel Araştırmalar Projeler Koordinatörlüğü tarafından desteklenmiştir (Proje no. 15202011).

Makale Atıfı: Gök ŞM, Türk Dağı H, Kara F, Arslan U, Fındık D. Klinik örneklerden izole edilen Enterococcus faecium ve Enterococcus faecalis izolatlarının antibiyotik direnci ve virülans faktörlerinin araştıııması. Mikrobiyol Bul 2020;54(1):26-39.

\section{öz}

Çevrede yaygın olarak bulunan enterokoklar iyi tanımlanmış virülans faktörleri ve toksinleri olmamasına rağmen ciddi enfeksiyonlara neden olur. Enterokokların virülans özelliklerinin bilinmesi, karmaşık patojenik yapılarını anlamak için önemlidir. Bu çalışmada çeşitli klinik örneklerden izole edilen Enterococcus faecium ve Enterococcus faecalis izolatlarının virülans faktörlerinin (asa1, hyl, cylA, efa, ebp, ace, esp, gelE, sprE, fsrA, fsrB, fsrC genleri, jelatinaz aktivitesi, hemolizin, hidrojen peroksit ve biyofilm üretimi) ve antibiyotik direncinin araştırılması amaçlanmıştır. Enfeksiyon etkeni olarak kabul edilen toplam 110 enterokok izolatı çalışmaya alınmıştır. İzolatların tür tanısı ve virülans genlerinin saptanması için polimeraz zincir reaksiyonu yöntemi kullanılmıştır. İzolatların hemoliz özelliği, biyofilm yapımı, hidrojen peroksit üretimi ve jelatinaz aktivitesi fenotipik yöntemlerle araştırımıştır. Antibiyotik duyarlılık testi VITEK 2 otomatize sistemi ile yapılmıştır. Tüm testlerde kalite kontrol olarak E.faecalis ATCC 29212 standart suşu kullanılmıştır. Çalışmaya alınan 110 enterokok izolatının 61'i E.faecium, 49'u E.faecalis olarak tanımlanmıştır. E.faecium ve E.faecalis izolatlarında en çok rastlanan virülans geni \%92.7'lik oran ile efa geni olmuştur. Diğer genlerden ace \%83.6, esp \%66.4, ebp \%60.0, cyl \%50.9, hyl \%46.4, asa1 \%45.5, gelE, sprE ve fsrC genleri \%33.6, fsrA \%12.7 ve fsrB \%11.8 oranında saptanmıştır. E.faecalis izolatlarında hyl dışındaki tüm genler daha yüksek oranda saptanmış ve aradaki fark istatistiksel olarak anlamlı bulunmuştur $(\mathrm{p}<0.05)$. E.faecalis izolatlarının $25(\% 51)^{\prime}$ inin, E.faecium izolatIarının 1 (\%1.6)'inin beta-hemoliz yaptığı saptanmış ve aradaki fark istatistiksel olarak anlamlı bulunmuştur $(\mathrm{p}=0.000)$. Yedi (\%11.5) E.faecium ve 4 (\%8.2) E.faecalis izolatının biyofilm yaptığı saptanmış ancak aradaki fark istatistiksel olarak anlamlı bulunmamıştır ( $p>0.05)$. İki (\%3.3) E.faecium ve 14 (\%28.6) E.faecalis izolatının jelatinaz aktivitesi gösterdiği tespit edilmiş ve iki tür arasındaki fark istatistiksel olarak anlamlı bulunmuş- 
tur $(p=0.000)$. Çalışmaya alınan izolatların hiçbirinde hidrojen peroksit üretimi saptanmamıştır. En yüksek direnç oranı siprofloksasine (\%70.9) karşı tespit edilmiştir. Ampisiline \%69.1, tetrasikline \%67.3, yüksek düzey streptomisine $\% 65.1$, yüksek düzey gentamisine $\% 39.4$, vankomisin ve teikoplanine $\% 4.5$, linezolide \%1.8 oranında direnç saptanmıştır. Sonuç olarak, çalışmamızda biyofilm üretimi ve hyl geni hariç virülans faktörlerinin E.faecalis izolatlarında daha yüksek oranda bulunduğu ancak E.faecium türlerinin antibiyotiklere daha dirençli olduğu saptanmıştır. Hastane ortamında bu tür virülansı yüksek veya dirençli izolatların enfeksiyonunu önlemek için, enfeksiyon kontrol önlemlerine uyulması gerekmektedir. Enterokokların virülansının daha iyi anlaşılması için in vivo çalışmalara gereksinim bulunmaktadır.

Anahtar kelimeler: Enterococcus faecalis; Enterococcus faecium; virülans faktörleri.

\section{ABSTRACT}

Enterococci, which are commonly found in the environment, cause serious infections despite the absence of well-defined virulence factors and toxins. Knowing the virulence properties of enterococci is important to understand the complex pathogenic structures. In this study, we aimed to investigate the virulence factors (asa1, hyl, cylA, efa, ebp, ace, esp, gelE, sprE, fsrA, fsrB, fsrC genes, gelatinase activity, hemolysin, hydrogen peroxide and biofilm production) and antibiotic resistance of Enterococcus faecium and Enterococcus faecalis strains isolated from clinical specimens. A total of 110 enterococcus isolates which were accepted as infectious agents were included in the study. The polymerase chain reaction method was used to identify the isolates and to detect virulence genes. Characteristics of hemolysis, biofilm formation, hydrogen peroxide production and gelatinase activity were investigated by phenotypic methods. The antibiotic susceptibility test was performed with VITEK 2 automated system. E.faecalis ATCC 29212 standard strain was used as a quality control in all tests. Of the 110 enterococci isolates included in the study, 61 were identified as E.faecium and 49 as E.faecalis. The efa gene was the most frequently detected virulence gene $(92.7 \%)$, followed by ace (83.6\%), esp (66.4\%), ebp (60.0\%), cylA (50.9\%), hyl (46.4\%), asa1 (45.5\%), gelE, sprE, fsrC (33.6\%), fsrA (12.7\%) and fsrB (11.8\%). All genes except hyl were higher in E.faecalis isolates and the difference was statistically significant $(p<0.05)$. Twenty-five (51\%) E.faecalis and $1(1.6 \%)$ E.faecium isolates had beta-hemolysis and the difference was statistically significant $(\mathrm{p}=0.000)$. Seven $(11.5 \%)$ E.faecium and 4 (8.2\%) E.faecalis isolates formed biofilm, but the difference was not statistically significant ( $p>0.05)$. Two (3.3\%) E.faecium and 14 (28.6\%) E.faecalis isolates exhibited gelatinase activity and the difference between the two species was statistically significant $(p=0.000)$. Hydrogen peroxide production was not detected in any of the isolates. The highest resistance rate was determined against ciprofloxacin (70.9\%). The resistance to ampicillin was $69.1 \%$, high level streptomycin $65.1 \%$, high level gentamicin $39.4 \%$, vancomycin and teicoplanin $4.5 \%$, and linezolid $1.8 \%$. In conclusion, our data indicated that virulence factors except hyl gene and biofilm production were higher in E.faecalis isolates but E.faecium isolates were more resistant to antibiotics. In order to prevent infection of such virulent or resistant isolates in the hospital setting, infection control measures must be followed. In vivo studies are needed for the better understanding of the virulence of enterococci.

Keywords: Enterococcus faecalis; Enterococcus faecium; virulence factors.

\section{Giriş}

Enterokoklar insan ve hayvanların gastrointestinal sistem florası üyeleridir. Doğada yaygın olarak bulunurlar. İnsanlarda esas olarak gastrointestinal florada bulunmaları nedeniyle gerek hastanede gerekse toplumda endojen kaynaklı enfeksiyonlara neden olurlar. Pek çok türü olmasına karşın insan enfeksiyonlarından sıklıkla Enterococcus faecalis ve Enterococcus faecium izole edilmektedir. Üriner sistem enfeksiyonları, yara enfeksiyonları, endokardit ve bakteriyemi etkenidirler. E.faecalis klinik örneklerden en sık izole edilen ve insan enfeksiyonlarında en sık görülen türdür. Son yıllarda hastane enfeksiyonlarının önemli bir etkeni olan E.faecium, E.faecalis'e göre antimikrobiyal ajanlara daha dirençlidir ${ }^{1,2}$. 
Enterokoklar klindamisin, penisilin, aminoglikozitler ve sefalosporinler dahil birçok antibiyotiğe karşı intrensek dirençli olmalarının yanı sıra diğer antibiyotiklere de kolaylıkla direnç geliştirebilir. E.faecium izolatlarının neredeyse tümü ampisiline dirençlidir ve günümüzde vankomisine de direnç kazanmaktadır. Ampisiline ve vankomisine dirençli enterokokların neden olduğu enfeksiyonların tedavisi için linezolid ve florokinolonlar gibi yeni antibiyotikler geliştirilmiştir. Maalesef linezolide direnç artmakta ve florokinolonlar vankomisine dirençli enterokok izolatlarına karşı zayıf etki göstermektedir ${ }^{2,3}$.

Fırsatçı patojen olan enterokokların klinikte artan önemine rağmen, virülansları günümüzde hala iyi anlaşılabilmiş değildir. Yakın zamanda yapılan çalışmalarda enterokoklar biyofilm oluşumu, jelatinaz üretimi, hemolizin, hiyalüronidaz, enterokok yüzey proteini ve agregasyon faktörü gibi virülans faktörleri ile ilişkilendirilmiştir. Enterokoklara özgü virülans faktörlerin büyük çoğunluğu plazmitler üzerinde kodlanır ve gastrointestinal sistem gibi doğal çevrede bulunan izolatlar arasında horizontal olarak hızla yayılmayı sağlar ${ }^{4,5}$.

Literatür taraması yapıldığında ülkemizde enterokoklarda virülans faktörlerinin araştırıldığı sınırlı sayıda çalışma bulunduğu ve virülans faktörlerinin birçoğunun (biyofilm oluşumu, ebp, efa, ace, sprE, fsrA, fsrB ve fsrC) araştırılmadığı belirlenmiştir. Bu çalışmanın amacı, klinik örneklerden enfeksiyon etkeni olarak izole edilen E.faecium ve E.faecalis izolatlarının antibiyotiklere direnç oranlarının ve virülans faktörlerinin (asa1, hyl, cylA, efa, ebp, ace, esp, gelE, fsrA, fsrB, fsrC, sprE genleri, jelatinaz aktivitesi, hemolizin varlığı, hidrojen peroksit ve biyofilm üretimi) araştırılmasıdır.

\section{GEREÇ ve YÖNTEM}

Bu çalışma, Selçuk Üniversitesi Tıp Fakültesi Girişimsel Olmayan Klinik Araştırmalar Etik Kurulu onayı ile gerçekleştirildi (Tarih: 04.11.2014 ve Karar no: 2014/284).

\section{Bakterilerin İzolasyonu ve Tanımlanması}

Selçuk Üniversitesi Tıp Fakültesi Tıbbi Mikrobiyoloji Laboratuvarında 2013-2015 yıllarında yatan hastaların klinik örneklerinden enfeksiyon etkeni olarak izole edilen 110 enterokok izolatı çalışmaya alındı. Klinik örnekler, \%5 koyun kanlı Columbia agara (bioMerieux, Fransa) ekildi ve plaklar $37^{\circ} \mathrm{C}^{\prime}$ de bir gece inkübe edildi. Üreyen bakteriler gelEneksel yöntemlerle [Gram boyama, katalaz testi, eskülin hidrolizi, \%6.5'lik NaCl içeren besiyerinde üreme ve PYR testi (L-pirolidonil- $\beta$-naftilamid)] ve VITEK 2 otomatize sistemi (bioMerieux, Fransa) ile tanımlandı.

\section{Antibiyotik Duyarlılık Testleri}

İzolatların ampisilin, eritromisin, siprofloksasin, tetrasiklin, vankomisin, teikoplanin ve linezolide karşı duyarlılık testleri VITEK 2 otomatize sistemi (bioMerieux, Fransa) ile yapıldı ve "Clinical and Laboratory Standard Institute (CLSI)" standartlarına göre değerlendirildi. Yüksek düzey gentamisin (YDG) direnci $500 \mu \mathrm{g} / \mathrm{ml}$, yüksek düzey streptomisin 
(YDS) direnci $1000 \mu \mathrm{g} / \mathrm{ml}$ düzeyinde VITEK 2 otomatize sistemi (bioMerieux, Fransa) ile tarandı. Üreme olması halinde bakteri dirençli kabul edildi ${ }^{6}$.

\section{Fenotipik Testler}

Hemolizin varlığının araştırılması için izolatlar \%5 koyun kanlı agara (bioMerieux, Fransa) ekildi ve $37^{\circ} \mathrm{C}^{\prime}$ de 48 saat inkübe edildi. Kolonilerin etrafında şeffaf bir zon oluşması beta-hemoliz (hemolizin üretimi) olarak değerlendirildi. Jelatinaz üretimi için \%5 koyun kanlı agarda (bioMerieux, Fransa) üremiş bakteri bir öze ile alınarak \%1.5 "skim milk" ile zenginleştirilmiş triptik soy agara (Oxoid, İngiltere) çizgi şeklinde ekildi. Besiyeri $37^{\circ} \mathrm{C}^{\prime}$ de 24 saat inkübe edildi. İnkübasyon sonunda üreyen kolonilerin etrafında berrak bir halo görülmesi pozitif olarak değerlendirildi? .

\section{Biyofilm Üretiminin Araştırılması}

Biyofilm üretiminin araştırılması için izolatların Luria Broth (LB) besiyerinde (Merck, Almanya) üç gün arka arkaya pasajları yapıldı. Üçüncü pasajı yapılan örneklerin absorbansı spektrofotometrede (S-22 UV/Vis. Cihazı BOECO-Almanya) 540 nm'de 0.56-0.64 olacak şekilde ayarlandı. Absorbansı ayarlanan örneklerden $200 \mu \mathrm{l} 96$ kuyucuklu mikroplağa aktarıldı ve kontrol kuyucuğuna sadece LB besiyeri kondu. Mikroplak $25^{\circ} \mathrm{C}^{\prime}$ de 24 saat inkübe edildi. Her kuyucuğa $25 \mu \mathrm{l}$ kristal viyole eklendi. Mikroplak çalkalandıktan sonra 15 dakika bekletildi. Kuyucuklardaki besiyeri çıkarılıp otomatik yıkama cihazında (BIOTEK-ABD ELx 50) fosfat tampon çözeltisi (PBS) ile üç kere yıkandı. Her bir kuyucuğa $200 \mu \mathrm{l} \% 96$ 'lık etanol eklendi. $590 \mathrm{~nm}$ dalga boyunda absorbansları ölçüldü (BiOTEKABD ELx800). Bakteri içeren kuyucuklardan elde edilen absorbans değerlerinden kontrol kuyucuğundan elde edilen değer çıkarıldı. Sonuç $0.1^{\prime}$ in üstünde ise pozitif, 0.1 'in altında ise negatif olarak kabul edildi ${ }^{8}$.

Hidrojen peroksit testi üretici firmanın (Quantofix Peroxide, Almanya) önerilerine göre yapıldı. $3 \mathrm{ml}$ beyin kalp infüzyon buyyon içeren tüplere birkaç koloni bakteri konuldu. Hidrojen peroksit test çubuğu, buyyonların içerisine daldırılıp 1-2 saniye sonra çıkartıldı. On-on beş saniye içinde test çubuğunda mavi renk oluşması beklendi. Oluşan renk tonu kit içeriğindeki renk skalasıyla karşılaştırılarak hidrojen peroksit miktarı belirlendi.

\section{DNA İzolasyonu ve Polimeraz Zincir Reaksiyonu}

DNA izolasyonu Qiagen DNA mini kit (Qiagen, Almanya) kullanılarak yapıldı. İzolatların tür tanısının doğrulanması ve ebp, asa1, esp, gelE, cylA, hyl, efa, ace, fsrA, fsrB, fsrC ve sprE virülans genlerinin saptanması için polimeraz zincir reaksiyonu (PCR) yöntemi kullanıldı (Tablo I).

\section{İstatistiksel Analiz}

Bu çalışmada E.faecium ve E.faecalis izolatlarında antibiyotik direnci ve virülans faktörlerinin dağılımı ki-kare ve Fisher kesin testi ile karşılaştırıldı ve $p<0.05$ değeri istatistiksel olarak anlamlı kabul edildi. 
Klinik Örneklerden İzole Edilen Enterococcus faecium ve Enterococcus faecalis İzolatlarının Antibiyotik Direnci ve Virülans Faktörlerinin Araştırılması

\begin{tabular}{|c|c|c|c|}
\hline Hedef gen & Primer Dizisi $\left(5^{\prime}-3^{\prime}\right)$ & Baz çifti & Kaynak \\
\hline \multirow[t]{2}{*}{ E.faecalis } & $d d \mathrm{EE}-1:$ ATC AAG TAC AGT TAG TCT TTA TTA G & \multirow[t]{2}{*}{941} & \multirow{2}{*}{$\begin{array}{l}\text { Kafil ve ark } \\
\quad(2013)\end{array}$} \\
\hline & ddIE-2: ACG ATT CAA AGC TAA CTG AAT CAG T & & \\
\hline \multirow[t]{2}{*}{ E.faecium } & ddIF-1: TTG AGG CAG ACC AGA TTG ACG & \multirow[t]{2}{*}{658} & \multirow{2}{*}{$\begin{array}{l}\text { Kafil ve ark }^{9} \\
\quad(2013)\end{array}$} \\
\hline & $d d \mathrm{~F}-2:$ TAT GAC AGC GAC TCC GAT TCC & & \\
\hline \multirow[t]{2}{*}{ asa1 } & asa-1: GCA CGC TAT TAC GAA CTA TGA & \multirow[t]{2}{*}{375} & \multirow{2}{*}{$\begin{array}{l}\text { Vankerckhoven } \\
\text { ve } \operatorname{ark}^{10}(2004)\end{array}$} \\
\hline & asa-2: TAA GAA AGA ACA TCA CCA CGA & & \\
\hline \multirow[t]{2}{*}{ gelE } & gel-F: TAT GAC AAT GCT TTT TGG GAT & \multirow[t]{2}{*}{213} & \multirow{2}{*}{$\begin{array}{l}\text { Vankerckhoven } \\
\text { ve } \operatorname{ark}^{10}(2004)\end{array}$} \\
\hline & gel-R: AGA TGC ACC CGA AAT AAT ATA & & \\
\hline \multirow[t]{2}{*}{ esp } & esp-F: AGA TTT CAT CTT TGA TTC TTG G & \multirow[t]{2}{*}{510} & \multirow{2}{*}{$\begin{array}{l}\text { Vankerckhoven } \\
\text { ve } \operatorname{ark}^{10}(2004)\end{array}$} \\
\hline & esp-R: AAT TGA TTC TTT AGC ATC TGG & & \\
\hline \multirow[t]{2}{*}{ Cy/A } & cyl-F: ACT CGG GGA TTG ATA GGC & \multirow[t]{2}{*}{688} & \multirow{2}{*}{$\begin{array}{l}\text { Vankerckhoven } \\
\text { ve } \operatorname{ar}^{\mathrm{k} 10}(2004)\end{array}$} \\
\hline & cyl-R: GCT GCT AAA GCT GCG CTT & & \\
\hline \multirow[t]{2}{*}{ hyl } & hyl-F: ACA GAA GAG CTG CAG GAA ATG & \multirow[t]{2}{*}{276} & \multirow{2}{*}{$\begin{array}{l}\text { Vankerckhoven } \\
\text { ve } \operatorname{ark}^{10}(2004)\end{array}$} \\
\hline & hyl-R: GAC TGA CGT CCA AGT TTC CAA & & \\
\hline \multirow[t]{2}{*}{$e b p$} & ebp-A: AAA AAT GAT TCG GCT CCA GAA & \multirow[t]{2}{*}{101} & \multirow{2}{*}{$\begin{array}{l}\text { Kafil ve ark } \\
\quad(2013)\end{array}$} \\
\hline & ebp-B: TGC CAG ATT CGC TCT CAA AG & & \\
\hline \multirow[t]{2}{*}{ ace } & ace-F: GGA GAG TCA AAT CAA GTA CGT TGG TT & \multirow[t]{2}{*}{101} & \multirow{2}{*}{$\begin{array}{l}\text { Kafil ve ark } \\
\quad(2013)\end{array}$} \\
\hline & ace-R: TGT TGA CCA CTT CCT TGT CGA T & & \\
\hline \multirow[t]{2}{*}{ efa } & efa-F: TGG GAC AGA CCC TCA CGA ATA & \multirow[t]{2}{*}{101} & \multirow{2}{*}{$\begin{array}{l}\text { Kafil ve ark } \\
\quad(2013)\end{array}$} \\
\hline & efa-R: CGC CTG TTT CTA AGT TCA AGC C & & \\
\hline \multirow[t]{2}{*}{ fsrA } & fsrA-F: GGG AGC TCT GAT GAT GAT TGA TTG ATG GAC & \multirow[t]{2}{*}{484} & \multirow{2}{*}{$\begin{array}{l}\text { Qin ve ark }{ }^{11} \\
(2000)\end{array}$} \\
\hline & fsrA-R: GGG GTA CCA TTA CAA GTG GCA CAC CAG GAC & & \\
\hline$f s r B$ & fsrB-F: GGG AGC TCT GGA CAA AGT ATT ATC TAA CCG & 574 & Qin ve $\operatorname{ark}^{11}$ \\
\hline & fsrB-R: TTG GTA CCC ACA CCA TCA CTG ACT TTT GC & & \\
\hline fsrC & fsrC-F: GGG AGC TCA TCG TGT GTT AGA AAA TAG C & 580 & Qin ve $\operatorname{ark}^{11}$ \\
\hline & fsrC-R: GGG GTA CCA CGA ATC ACA ACC ACT AAG TC & & \\
\hline sprE & sprE-F: CTT GTC TGC AAA TGC AGA AG & 660 & Lindenstraub \\
\hline & sprE-R: CGC CAT TGG AAT GAA CAC CA & & ve $\operatorname{ark}^{12}(2011)$ \\
\hline
\end{tabular}

\section{BULGULAR}

Çalışmaya alınan toplam 110 Enterococcus spp. izolatının 61'i E.faecium, 49'u E.faecalis olarak tanımlanmıştır. E.faecium ve E.faecalis izolatlarının örneklere göre dağılımı Tablo II'de gösterilmiştir. Üreyen tür ile klinik örnek arasında istatistiksel olarak anlamlı fark bulunmamıştır ( $p>0.05)$.

E.faecium ve E.faecalis izolatlarında en yüksek direnç oranı siprofloksasine (\%70.9) karşı tespit edilmiştir. Ampisiline \%69.1, tetrasikline \%67.3, YDS'ye \%65.1, YDG'ye \%39.4, 
Tablo II. Enterococcus faecium ve Enterococcus faecalis Izolatlarının Örneklere Göre Dağılımı

\begin{tabular}{lcccccc}
\hline & \multicolumn{2}{c}{ E.faecium } & \multicolumn{2}{c}{ E.faecalis } & \multicolumn{2}{c}{ Toplam } \\
\cline { 2 - 7 } & Sayı & Yüzde & Sayı & Yüzde & Sayı & Yüzde \\
\hline İdrar & 43 & 70.5 & 38 & 77.6 & 81 & 73.6 \\
Kan & 15 & 24.6 & 7 & 14.3 & 22 & 20.0 \\
Yara/Apse & 3 & 4.9 & 4 & 8.2 & 7 & 6.4 \\
Toplam & 61 & 55.5 & 49 & 44.5 & 110 & 100 \\
\hline \multicolumn{7}{r}{} \\
\end{tabular}

vankomisin ve teikoplanine \%4.5, linezolide \%1.8 oranında direnç saptanmıştır. Antibiyotiklere direnç oranlarının E.faecium izolatlarında E.faecalis izolatlarına göre daha yüksek olduğu görülmüştür. Aradaki fark ampisilin, siprofloksasin, tetrasiklin ve YDS için istatistiksel olarak anlamlı bulunurken, diğer antibiyotikler için anlamlı bulunmamıştır (Tablo III).

Enterokok izolatlarının hemoliz özelliği değerlendirildiğinde; 49 E.faecalis izolatının 25 (\%51)'inin, 61 E.faecium izolatının 1 (\%1.6)'inin beta-hemoliz yaptığı saptanmış ve aradaki fark istatistiksel olarak anlamlı bulunmuştur $(\mathrm{p}=0.000)$ (Resim 1).

E.faecium izolatlarının 7 (\%11.5)'sinin ve E.faecalis izolatlarının 4 (\%8.2)'ünün biyofilm yaptığı saptanmış ancak aradaki fark istatistiksel olarak anlamlı bulunmamıştır $(p=0.752)$ (Resim 2).

On dört (\%28.6) E.faecalis ve 2 (\%3.3) E.faecium izolatının jelatinaz aktivitesi gösterdiği tespit edilmiş ve aradaki fark istatistiksel olarak anlamlı bulunmuştur $(p=0.000)$ (Resim 3).

Çalışmaya alınan enterokok izolatlarının hiçbirinde hidrojen peroksit üretimi saptanmamıştır (Resim 4). Klinik örneklerle hemolizin varlığı, jelatinaz aktivitesi ve biyofilm üretimi arasında istatistiksel olarak anlamlı bir ilişki tespit edilmemiştir ( $p>0.05)$.

\begin{tabular}{|c|c|c|c|c|c|c|c|}
\hline \multirow[b]{2}{*}{ Antibiyotik } & \multicolumn{2}{|c|}{ E.faecium $(n=61)$} & \multicolumn{2}{|c|}{ E.faecalis $(n=49)$} & \multirow[b]{2}{*}{$\mathrm{p}$} & \multicolumn{2}{|c|}{ Toplam $(n=110)$} \\
\hline & Sayı & Yüzde & Sayı & Yüzde & & Sayı & Yüzde \\
\hline Siprofloksasin & 56 & 91.8 & 22 & 44.9 & 0.000 & 78 & 70.9 \\
\hline Ampisilin & 57 & 93.4 & 19 & 38.8 & 0.000 & 76 & 69.1 \\
\hline Tetrasiklin & 33 & 54.1 & 41 & 83.7 & 0.001 & 74 & 67.3 \\
\hline YDS & 45 & 73.8 & 26 & 54.2 & 0.043 & 71 & 65.1 \\
\hline YDG & 23 & 37.7 & 20 & 41.7 & 0.697 & 43 & 39.4 \\
\hline Vankomisin & 5 & 8.2 & 0 & 0 & 0.064 & 5 & 4.5 \\
\hline Teikoplanin & 5 & 8.2 & 0 & 0 & 0.064 & 5 & 4.5 \\
\hline Linezolid & 2 & 3.3 & 0 & 0 & 0.728 & 2 & 1.8 \\
\hline
\end{tabular}




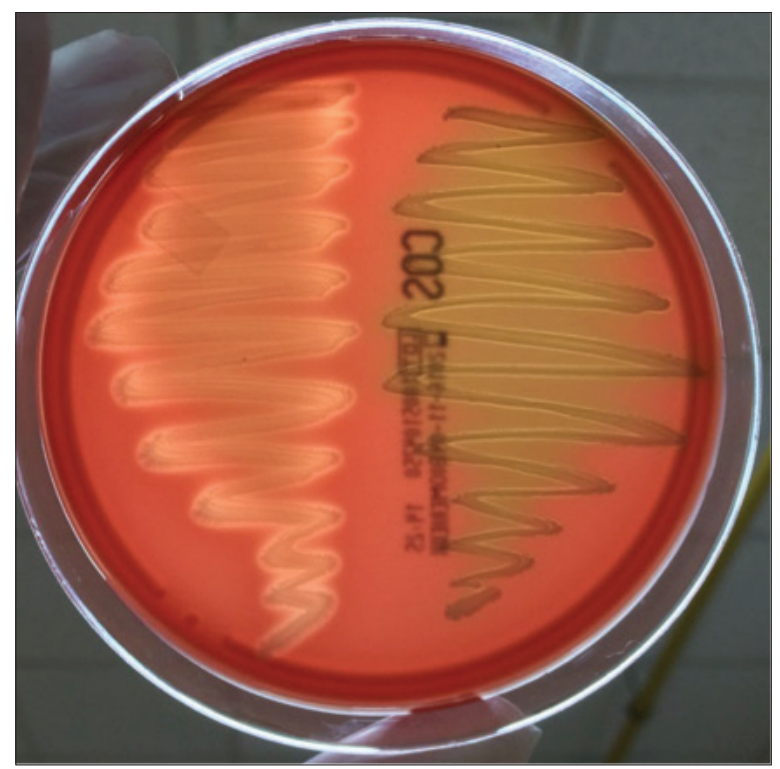

Resim 1. Beta (sol) ve alfa (sağ) hemoliz yapan Enterococcus faecalis ve Enterococcus faecium izolatları.

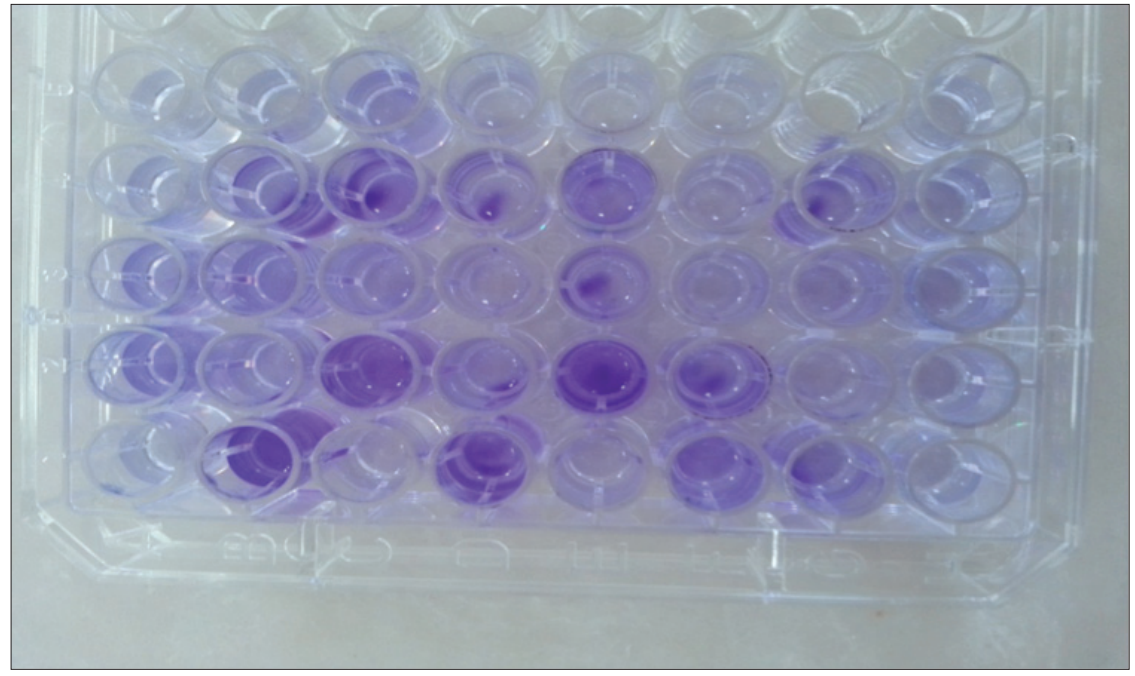

Resim 2. Mikroplak yöntemi ile biyofilm üretimi saptanması.

Virülans genleri arasında efa (\%92.7) ve ace (\%83.6) en sık saptanan genler olmuştur. hyl dışındaki tüm genler E.faecalis izolatlarında daha yüksek oranda saptanmış ve aradaki fark istatistiksel olarak anlamlı bulunmuştur $(\mathrm{p}<0.05)$. hyl geni ise E.faecium izolatlarında daha yüksek oranda tespit edilmiş ancak aradaki fark istatistiksel olarak anlamlı bulunmamıştır $(p=0.085)$ (Tablo IV). Klinik örneklerle efa hariç diğer genler arasında istatistiksel olarak anlamlı bir ilişki tespit edilmemiştir ( $p>0.05)$. efa geni kan örneklerinde diğer örneklere 


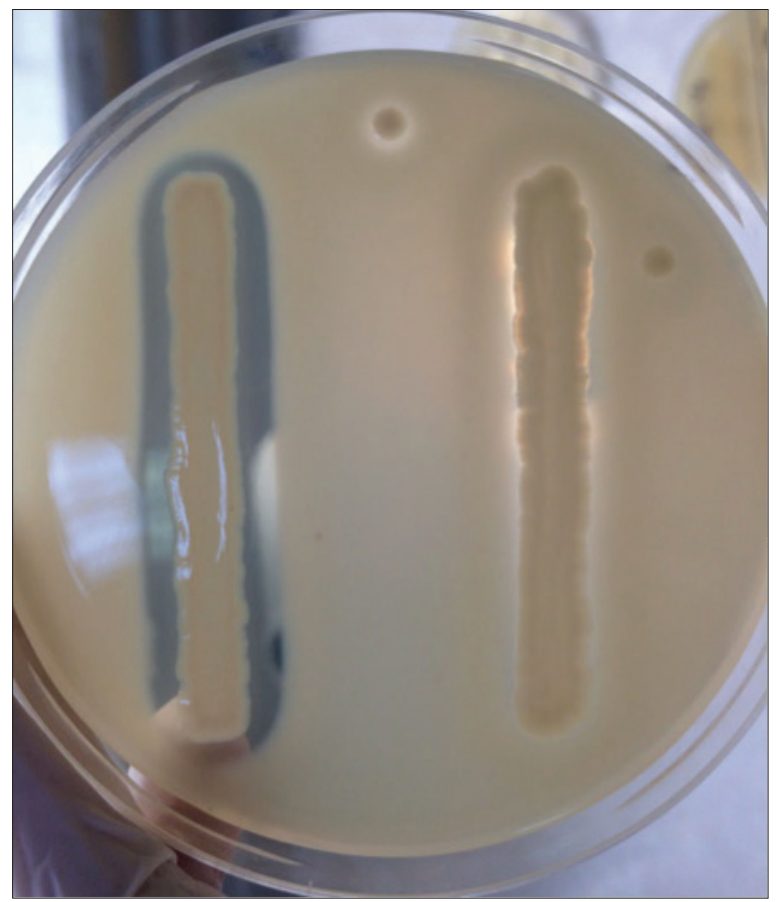

Resim 3. Jelatinaz aktivitesi pozitif (sol) ve negatif (sağ) izolat.

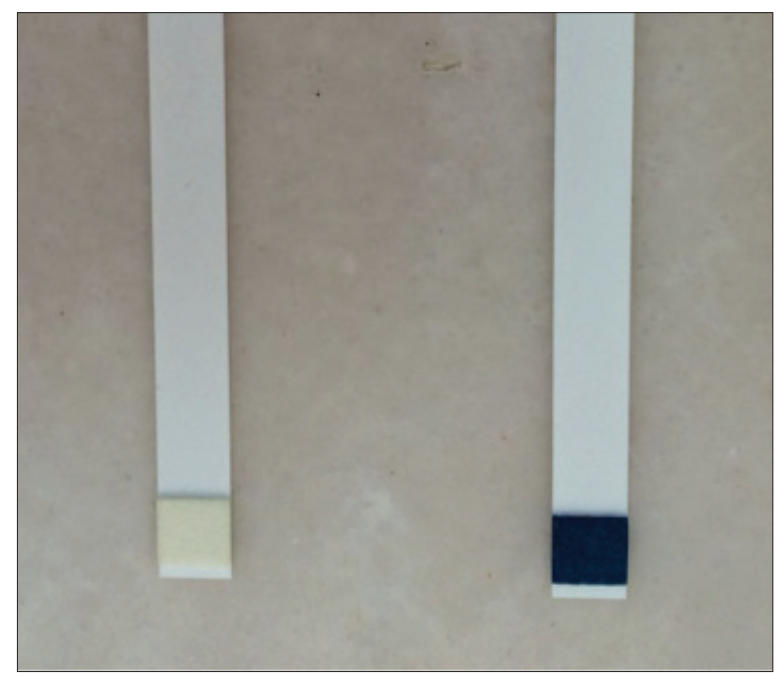

Resim 4. Hidrojen peroksit aktivitesi negatif (sol) ve pozitif (sağ) (Enterococcus faecalis ATCC 29212 standart suşunun hidrojen peroksit aktivitesi pozitiftir). 
Klinik Örneklerden İzole Edilen Enterococcus faecium ve Enterococcus faecalis İolatlarının Antibiyotik Direnci ve Virülans Faktörlerinin Araştırılması

\begin{tabular}{|c|c|c|c|c|c|c|c|}
\hline \multirow{2}{*}{$\begin{array}{l}\text { Virülans } \\
\text { faktörleri }\end{array}$} & \multicolumn{2}{|c|}{ E.faecium $(n=61)$} & \multicolumn{2}{|c|}{ E.faecalis $(n=49)$} & \multirow[b]{2}{*}{$\mathbf{p}$} & \multicolumn{2}{|c|}{ Toplam $(n=110)$} \\
\hline & Sayı & Yüzde & Sayı & Yüzde & & Sayı & Yüzde \\
\hline Hemolizin & 1 & 1.6 & 25 & 51.0 & 0.000 & 26 & 23.6 \\
\hline Biyofilm & 7 & 11.5 & 4 & 8.2 & 0.752 & 11 & 10.0 \\
\hline Jelatinaz & 1 & 1.6 & 13 & 26.5 & 0.000 & 14 & 12.7 \\
\hline$e b p$ & 19 & 31.1 & 47 & 95.9 & 0.000 & 66 & 60.0 \\
\hline asa1 & 22 & 36.1 & 28 & 57.1 & 0.035 & 50 & 45.5 \\
\hline esp & 34 & 55.7 & 39 & 79.6 & 0.009 & 73 & 66.4 \\
\hline cylA & 22 & 36.1 & 34 & 69.4 & 0.001 & 56 & 50.9 \\
\hline hyl & 33 & 54.1 & 18 & 36.7 & 0.085 & 51 & 46.4 \\
\hline efa & 53 & 86.9 & 49 & 100 & 0.008 & 102 & 92.7 \\
\hline ace & 43 & 70.5 & 49 & 100 & 0.000 & 92 & 83.6 \\
\hline gelE & 5 & 8.2 & 32 & 65.3 & 0.000 & 37 & 33.6 \\
\hline sprE & 5 & 8.2 & 32 & 65.3 & 0.000 & 37 & 33.6 \\
\hline$f s r A$ & 1 & 1.6 & 13 & 26.5 & 0.000 & 14 & 12.7 \\
\hline$f_{s r} B$ & 1 & 1.6 & 12 & 24.5 & 0.000 & 13 & 11.8 \\
\hline fsrC & 5 & 8.2 & 32 & 65.3 & 0.000 & 37 & 33.6 \\
\hline
\end{tabular}

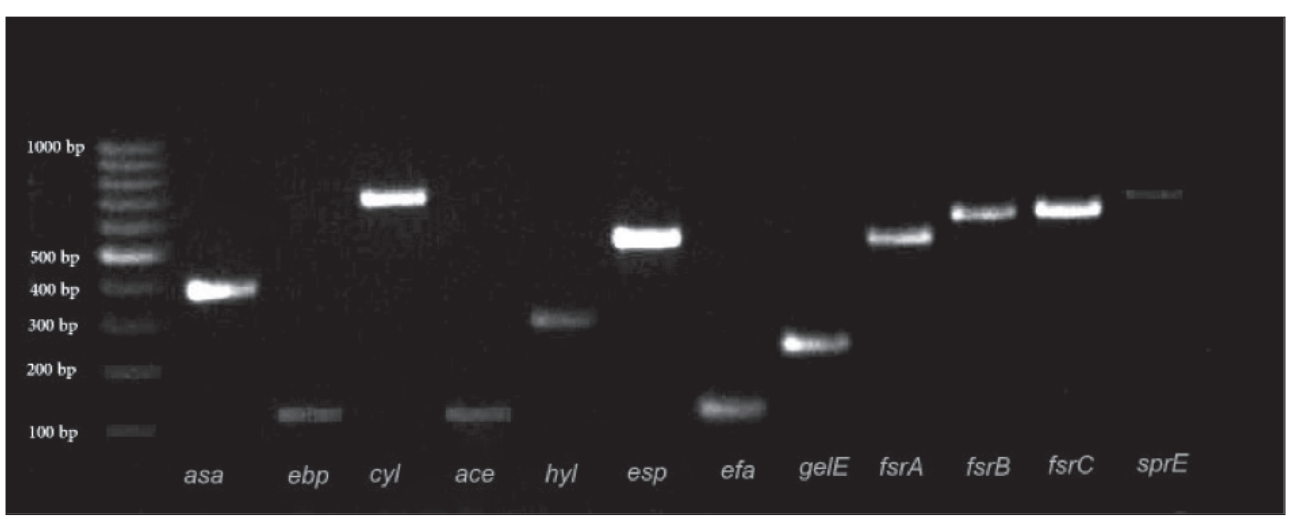

Resim 5. Enterococcus faecalis ve Enterococcus faecium izolatlarında $P C R$ ile saptanan virülans genlerinin jel görüntüsü. asa: 375 baz çifti (bp), ebp: 101 bp, cyl: 688 bp, ace: 101 bp, hyl: 276 bp, esp: 510 bp, efa: 101 bp, gelE: 213 bp, fsrA: 484 bp, fsrB: 574 bp, fsrC: 580 bp ve sprE: 660 bp.

göre daha düşük oranda tespit edilmiş ve aradaki fark istatistiksel olarak anlamlı bulunmuştur $(p=0.013)$.

PCR ile saptanan virülans genlerinin örnek jel görüntüleri Resim 5'te gösterilmiştir. 


\section{TARTIŞMA}

Son yıllarda enterokoklar ciddi hastane enfeksiyonlarına neden olan patojenler olarak ortaya çıkmışlardır. Pek çok antimikrobiyal ilaca karşı direnç göstermeleri, geniş spektrumlu antibiyotik tedavisi alan hastalarda üremelerine ve süperenfeksiyonlara neden olmaktadır. Klasik olarak E.faecalis'in daha çok enfeksiyon oluşturduğu, E.faecium'un ise antibiyotiklere daha dirençli olduğu bilinmektedir ${ }^{13}$. Çalışmamızda E.faecium izolatlarının ampisilin, siprofloksasin, YDS, vankomisin, teikoplanin ve linezolide E.faecalis izolatlarına göre daha dirençli, tetrasiklin ve YDG'ye ise daha duyarlı oldukları tespit edilmiştir. Bu fark ampisilin, siprofloksasin, tetrasiklin ve YDS için istatistiksel olarak anlamlı bulunurken, diğer antibiyotikler için anlamlı bulunmamıştır (Tablo III). Ülkemizde yapılan benzer bir çalışmada da ampisilin, penisilin ve vankomisine E.faecium izolatlarının E.faecalis izolatlarına göre daha dirençli olduğu saptanmıştır ${ }^{14}$.

Enterokoklarda plazmitlere direnç gösteren izolatların sayısı giderek artmaktadır. Kafil ve arkadaşları ${ }^{9}$ İran'da yaptıkları çalışmada vankomisin direncini E.faecalis ve E.faecium için sırasıyla \%16.3 ve \%33.8 olarak bildirmişlerdir. Ülkemizde Baylan ve arkadaşlarının yaptıkları çalışmada E.faecalis izolatlarında vankomisine direnç görülmezken, E.faecium izolatlarında \%25.8 oranında direnç tespit edilmiştir. Çalışmamızda vankomisin ve teikoplanin direnci 5 (\%8.2) E.faecium izolatında tespit edilmiş, E.faecalis izolatlarında saptanmamıştır. Bu düşük glikopeptit direncinin nedeni, sadece enfeksiyon etkeni kabul edilen izolatlar çalışmaya dahil edildiği için dışkı izolatlarının alınmaması olabilir. Ayrıca proje kaynakları kısıtlı olduğu için çalışma belli sayıda izolatla sınırlandırılmıştır.

Enterokoklarda yüksek düzey aminoglikozit direnci, endokardit ve bakteriyemi gibi ciddi enfeksiyonların tedavisinde zorluklara neden olmaktadır. Çalışmamızda YDG direnci E.faecalis izolatlarında (\%41.7) E.faecium'a (\%37.7) göre daha yüksek oranda tespit edilmiş ancak iki tür arasında YDG direnci açısından istatistiksel olarak anlamlı fark bulunmamıştır. YDS direnci ise E.faecium izolatlarında (\%73.8) E.faecalis'e (\%54.2) göre daha yüksek saptanmış ve fark istatistiksel olarak anlamlı bulunmuştur $(p=0.043)$. Ülkemizde yapılan bir çalışmada da benzer olarak YDG direnci E.faecalis'de \%47.1, E.faecium'da \%40.7, YDS direnci ise E.faecalis'de \%55.8, E.faecium' da \%63.7 olarak bildirilmiştir ${ }^{14}$. Ancak Baylan ve arkadaşları $^{7}$ hem YDG hem de YDS direncini E.faecium'da daha yüksek oranda saptamışlardır. Bu farkın çalışmaya alınan izolat sayısına, izolatların soyutlandığı klinik örneklere, etken ya da kolonizan olmalarına göre değişkenlik gösterebileceği düşünülmüştür.

Linezolid, günümüzde dirençli gram-pozitif bakterilerin etken olduğu enfeksiyonlar için önemli bir tedavi seçeneğidir. Linezolide direnç Türkiye'de ilk defa Aktaş ve arkadaşları ${ }^{15}$ tarafından E.faecium izolatlarında \%2 oranında bildirilmiştir. Çalışmamızda E.faecium izolatlarında \%1.8 oranında linezolide direnç belirlenmiş, E.faecalis izolatlarında ise saptanmamıştır. Patel ve arkadaşları ${ }^{16}$ da sadece E.faecium izolatlarında linezolide direnç (\%0.4) bildirmişlerdir.

Enterokoklarda enfeksiyonun şiddetini artırması nedeniyle hemolizin üretimi virülansta büyük öneme sahiptir. Hasani ve arkadaşları ${ }^{17}$ E.faecalis izolatlarının \%19.5'inin beta-he- 
molitik özellikte olduğunu tespit etmişlerdir. Brezilya'da yapılan bir çalışmada izolatların hemolizin üretme oranı $\% 38$ olarak bildirilmiştir ${ }^{18}$. Bizim çalışmamızda E.faecalis izolatlarının \%51'inin, E.faecium izolatlarının ise \%1.6'sının hemolizin ürettiği tespit edilmiştir. Ülkemizde Baylan ve arkadaşları ${ }^{7}$ hemolizin üretimini E.faecalis izolatlarında \%16.9 olarak bildirmişler, E.faecium izolatlarında saptamamışlardır. Ancak başka bir çalışmada E.faecalis izolatlarında bizim çalışmamıza benzer oranda (\%42.8) tespit edilirken, E.faecium izolatlarında oldukça yüksek oranda (\%31.9) saptanmıştır ${ }^{14}$. Bunun nedeninin fenotipik testlerin değerlendirilmesinde kişisel yorum ve izolat farkı olabileceği düşünülmüştür.

Jelatinaz, kollajen, fibrinojen, fibrin ve kompleman bileşenleri gibi konak substratlarının parçalayarak virülansa katkıda bulunduğu hücre dışı bir çinko-metalloproteazdır. Soares ve arkadaşları ${ }^{19}$ jelatinaz pozitifliğini E.faecalis izolatlarında \%33.5, E.faecium izolatlarında ise \%5.3 oranında bildirmişlerdir. Bizim çalışmamızda da jelatinaz pozitifliği E.faecalis izolatlarında \%26.5, E.faecium izolatlarında \%1.6 saptanmış, iki tür arasındaki fark istatistiksel olarak anlamlı bulunmuştur $(p=0.000)$. Ülkemizde yapılan çalışmalarda da benzer sonuçlar bildirilmiştir ${ }^{7,14}$.

Bakterilerdeki biyofilm yapısı, patojen bakterileri birçok dezenfektan ve antimikrobiyallerden koruyarak tedavisi güç kronik enfeksiyonlara yol açmaktadır. Soares ve arkadaşla$\mathrm{rı}^{19}$ E.faecalis izolatlarının \%87.3'ünün, E.faecium izolatlarının \%10.5'inin biyofilm ürettiğini, noninvaziv izolatlar ve biyofilm oluşumu arasında istatistiksel olarak anlamlı bir ilişki olduğunu bildirmişlerdir. Çalışmamızda E.faecium izolatlarının 7 (\%11.5)'sinde, E.faecalis izolatlarının 4 (\%8.2)'ünde biyofilm üretimi tespit edilmiş ancak aradaki fark istatistiksel olarak anlamlı bulunmamıştır $(p=0.752)$. Enterokoklarda biyofilm oluşumu karmaşık ve çok faktörlüdür; bu nedenle virülans faktörleri arasındaki yeri tartışmalıdır ${ }^{20}$.

Bir plazmit (asa1 geni) tarafından kodlanan agregasyon faktörü, bakterinin renal tübüler hücrelere adezyonunu ve insan makrofajlarına bağlanmasını sağlamaktadır. Sharifi ve arkadaşları yaptıkları çalışmada ${ }^{13}$ asa1 gen pozitifliğini E.faecalis izolatlarında \%69.8, E.faecium izolatlarında ise $\% 8$ olarak bildirmişlerdir. Çalışmamızda da asa1 gen pozitifliği E.faecalis izolatlarında (\%57.1), E.faecium izolatlarına (\%36.1) göre yüksek oranda tespit edilmiş ve aradaki fark istatistiksel olarak anlamlı bulunmuştur $(p=0.035)$. Ülkemizde yapılan bir çalışmada da asa1 geni E.faecalis izolatlarında E.faecium izolatlarına göre anlamIı düzeyde yüksek bulunmuştur ${ }^{14}$. Bu veriler asa1 geninin E.faecalis'de E.faecium'a göre daha yaygın bir virülans faktörü olduğunu göstermektedir.

Enterokokların kolonizasyonu ve biyofilm oluşumunda rol alan hücre duvarı ile ilişkili proteinlerden biri enterokok yüzey proteinidir (esp). Malezya'da yapılan bir çalışmada esp geni E.faecalis izolatlarında \%49.2, E.faecium izolatlarında ise \%30.8 oranında bildirilmiştir ${ }^{21}$. Çalışmamızda esp geni E.faecalis izolatlarında \%79.6, E.faecium izolatlarında \%55.7 oranında saptanmıştır. Saba Çopur ve arkadaşları ${ }^{22}$ E.faecalis izolatlarında \%73.9, E.faecium izolatlarında ise \%79.6 oranında esp pozitifliği bildirmişlerdir. esp'nin E.faecium'da saptanan tek virülans geni olduğu ve dünyadaki hastane salgınlarıyla ilişkili olan E.faecium'un özel bir soyu olan klonal kompleks 17'nin önemli bir özelliği olduğu bil- 
dirilmiştir ${ }^{23}$. Ancak bizim çalışmamızda ve ülkemizde yapılan diğer çalışmada E.faecium izolatlarında esp ile birlikte birçok virülans geni saptanmıştır²2.

Prokaryot ve ökaryot hücreleri lizise uğratma yeteneğine sahip olan sitolizin cyl genleri tarafından kodlanır. İran'da yapılan bir çalışmada cyl gen pozitifliği E.faecalis izolatlarında $\% 30.4$, E.faecium izolatlarında ise \%11 olarak bildirilmiştir ${ }^{23}$. Çalışmamızda, E.faecalis izolatlarında \%69.4, E.faecium izolatlarında \%36.1 oranında cylA geni tespit edilmiştir. Saba Çopur ve arkadaşları ${ }^{22}$ yaptıkları çalışmada E.faecalis izolatlarında $c y l A$ genini \%27.3, E.faecium'da ise \%2.2 oranında bildirmişlerdir. Ülkemizde yapılan bu iki çalışma arasındaki farkın çalışmaya alınan izolatların soyutlandığı klinik örneklerden, etken ya da kolonizan olmalarından kaynaklanabileceği düşünülmüştür.

Hiyalüronidaz enzimi bağ dokusundaki mukopolisakkaritleri ve hiyalüronik asidi parçalayarak doku hasarına ve bakterinin yayılmasına neden olmaktadır. Çalışmamızda hyl geni diğer genlerden farklı olarak E.faecium izolatlarında (\%54.1) E.faecalis izolatlarına (\%36.7) göre daha yüksek oranda saptanmış ancak bu fark istatistiksel olarak anlamlı bulunmamıştır. Ülkemizde yapılan çalışmalarda da hyl geni E.faecium izolatlarında (\%38.7-15.1) E.faecalis'e (\%1.7-4.3) göre oldukça yüksek bildirilmiştir ${ }^{7,22}$. Arabestani ve arkadaşları ${ }^{24} \mathrm{da}$ hyl genini E.faecium'da (\%71.6) E.faecalis'e (\%56.6) göre daha yüksek tespit etmişlerdir. Bu durum, bakterinin dokulara invazyonunu sağlayan hiyalüronidaz enziminin E.faecium'un invaziv örneklerden daha çok izole edilmesinin bir nedeni olabileceğini göstermektedir.

E.faecalis antijen A proteinin, enterokokların adezyonunu sağladığı bildirilmekle birlikte enfeksiyondaki rolü hala tartışmalıdır. Lindenstraub ve arkadaşları ${ }^{12}$ efa genini E.faecalis izolatlarının \%65'inde, 10 E.faecium izolatının tümünde tespit etmişlerdir. Heidari ve arkadaşları ${ }^{23}$ da E.faecalis izolatlarında \%100, E.faecium izolatlarında ise \%22 oranında efa gen pozitifliği saptamışlardır. Bizim çalışmamızda efa en yüksek oranda belirlenen virülans genidir ve E.faecalis izolatlarının tamamında, E.faecium izolatlarının ise \%86.9'unda tespit edilmiştir. Ayrıca efa geni kan örneklerinde diğer örneklere göre daha düşük oranda tespit edilmiş ve aradaki fark istatistiksel olarak anlamlı bulunmuştur ( $p=$ 0.013). Bunun nedeni enterokokların coğrafi kökenlerine göre genetik olarak birbirlerinden farklı olması ve izole edilen örneklerin çeşitliliği olabilir.

Adeziv matriks molekülleri ailesine ait kollajen bağlayan protein olan ace'nin klinik izolatlarda fekal izolatlardan daha fazla olduğu belirtilmiştir ${ }^{25}$. İran'da yapılan bir çalışmada ace geni E.faecalis izolatlarında \%89.1 oranında, E.faecium'da ise bir izolatta tespit edilmiştir ${ }^{23}$. Tunus'ta yapılan bir çalışmada ace geni E.faecalis'de \%64.7, E.faecium'da \%35 oranında bildirilmiştir ${ }^{26}$. Çalışmamızda ace geni E.faecalis izolatlarında \%100, E.faecium izolatlarında \%70.5 oranında saptanmıştır.

Jelatinaz, gelE tarafından kodlanan bir çinko metalloproteazdır ve doku invazyonunda önemli bir rolü vardır. Bizim çalışmamızda E.faecalis izolatlarında \%65.3, E.faecium izolatlarında \%8.2 oranında gelE geni tespit edilmiş ve fark istatistiksel olarak anlamlı bulunmuştur. Soares ve arkadaşları ${ }^{19}$ E.faecalis izolatlarında \%78.7, E.faecium'da \%10.5 oranında sapta- 
mışlardır. Ülkemizde Saba Çopur ve arkadaşları ${ }^{22}$ E.faecalis'de \%52.2, E.faecium'da \%3.2; Mete ve arkadaşları ${ }^{14}$ E.faecalis'de \%12.3, E.faecium'da \%1.1 oranında gelE geni tespit ettiklerini bildirmişlerdir. Bu durum, E.faecalis'in virülansında gelE'nin önemini göstermektedir.

Serin proteaz E.faecalis tarafından salgılanan proteazlardan biridir ve üriner sistem enfeksiyonlarında virülans için gereklidir. Al-Talib ve arkadaşları ${ }^{21}$ yaptıkları bir çalışmada sprE genini E.faecalis izolatlarında \%76, E.faecium'da ise \%66.7 oranında bildirmişlerdir. Çalışmamızda E.faecalis'de \%65.3, E.faecium'da \%8.2 oranında sprE geni pozitifliği tespit edilmiştir. gelE-sprE genleri aynı operonda transkript edilmekte ve ekspresyonları Fsr-quorum sensing systemi tarafından kontrol edilmektedir ${ }^{27}$. Golinska ve arkadaşları ${ }^{28}$ yaptıkları çalışmada 16 E.faecalis izolatında bir $f s r A$, iki fsrB ve altı fsrC; sekiz E.faecium izolatında ise iki $f s r A$, bir $f s r B$ ve bir $f_{s r C}$ bildirmişlerdir. Çalışmamızda, E.faecalis izolatlarında $13 \mathrm{fsrA}, 12 \mathrm{fsrC}, 32 \mathrm{fsrC}$; E.faecium izolatlarında ise bir fsrA, bir fsrB ve beş fsr $C$ geni tespit edilmiştir. Bu sonuç çalışmaya alınan izolatlarda gelE-sprE genlerinin ekspresyonlarının fsr genleri tarafından kontrol edildiğini göstermektedir.

Sonuç olarak, çalışmamızda biyofilm üretimi ve hyl geni hariç virülans faktörlerinin E.faecalis izolatlarında daha yüksek oranda bulunduğu ve E.faecium türlerinin ise antibiyotiklere daha dirençli olduğu saptanmıştır. Hastane ortamında bu tür virülans veya dirençli izolatların enfeksiyonunu önlemek için enfeksiyon kontrol önlemlerine uyulması gerekmektedir. Enterokokların virülansının daha iyi anlaşılması için in vivo çalışmalara gereksinim bulunmaktadır.

\section{ÇIKAR ÇATIŞMASI}

Yazarlar bu makale ile ilgili herhangi bir çıkar çatışması bildirmemişlerdir.

\section{KAYNAKLAR}

1. Teixeira LM, Siqueira Carvalho MDG, Facklam RR. Enterococcus, pp: 430-42. In: Murray PR, Baron EJ, Jorgensen JH, Landry ML, Pfaller MA (eds), Manual of Clinical Microbiology. 2007, $9^{\text {th }}$ ed. ASM Press, Washington DC.

2. Paganelli FL, Huebner J, Singh KV, Zhang X, van Schaik W, Wobser D, et al. Genome-wide screening identifies phosphotransferase system permease BepA to be involved in Enterococcus faecium endocarditis and biofilm formation. J Infect Dis 2016;214(2):189-95.

3. Arias CA, Murray BE. The rise of the Enterococcus: beyond vancomycin resistance. Nat Rev Microbiol 2012;10(4):266-78.

4. Comerlato CB, de Resende MC, Caierao J, d'Azevedo PA. Presence of virulence factors in Enterococcus faecalis and Enterococcus faecium susceptible and resistant to vancomycin. Mem Inst Oswaldo Cruz 2013;108(5):590-5.

5. Diani M, Ariofar MN, Akçelik N. İnsan ve hayvan sağlığı açısından risk oluşturan enterokokal biyofilm yapısının doğası. Turk Hij Den Biyol Derg 2016;73(1):71-80.

6. Clinical and Laboratory Standards Institute. Performance Standards for Antimicrobial Susceptibility Testing; Twenty-Third Informational Supplement. CLSI document M100-S23. Clinical and Laboratory Standards Institute, Wayne, Pennsylvania USA, 2013.

7. Baylan O, Nazik H, Bektöre B, Çitil BE, Turan D, Öngen B ve ark. Üriner enterokok izolatlarının antibiyotik direnci ile virülans faktörleri arasındaki ilişki. Mikrobiyol Bul 2011;45(3):430-45. 
8. El Fertas-Aissani R, Messai Y, Alouache S, Bakour R. Virulence profiles and antibiotic susceptibility patterns of Klebsiella pneumoniae strains isolated from different clinical specimens. Pathol Biol 2012;61(5):209-16.

9. Kafil HS, Mobarez AM, Moghadam MF. Adhesion and virulence factor properties of enterococci isolated from clinical samples in Iran. Indian J Pathol and Microbiol 2013;56(3):238-42.

10. Vankerckhoven V, Van Autgaerden T, Vael C, Lammens C, Chapelle S, Rossi R, et al. Development of a multipex PCR for the detection of asa1, gelE, cylA, esp, and hyl genes in enterococci and survey for virulence determinants among European hospital isolates of Enterococcus faecium. J Clin Microbiol 2004;42(10):4473-9.

11. Qin X, Singh KV, Weinstock GM, Murray BE. Effects of Enterococcus faecalis fsr genes on production of gelatinase and a serine protease and virulence. Infect Immun 2000;68(5):2579-86.

12. Lindenstraub AG, Pavlovic M, Bringmann A, Behr J, Ehrmann MA, Vogel RF. Comparison of genotypic and phenotypic cluster analysess of virulence determinants and possible role of CRISPR elements towards their incidence in Enterococcus faecalis and Enterococcus faecium. Syst Apple Microbiol 2011;34(8):553-60.

13. Sharifi Y, Hasani A, Ghotaslou R, Naghili B, Aghazadeh M, Milani M, et al. Virulence and antimicrobial resistance in enterococci isolated from urinary tract infections. Adv Pharm Bull 2013;3(1):197-201.

14. Mete E, Kaleli i, Cevahir N, Demir M, Akkaya Y, Kiriş Satılmış Ö. Enterokok türlerinin virulans faktörlerinin araştırılması. Mikrobiyol Bul 2017;51(2):101-14.

15. Aktaş G, Bozdoğan B, Derbentli ş. Linezolid ve dalbavansinin vankomisine dirençli enterokok izolatlarına karşı in vitro aktivitesi. Mikrobiyol Bul 2012;46(3):359-65.

16. Patel SN, Memari N, Shahinas D, Toye B, Jamieson FB, Farrell DJ. Linezolid resistance in Enterococcus faecium isolated in Ontario, Canada. Diagn Microbiol Infect Dis 2013;77(4):350-3.

17. Hasani A, Sharifi Y, Ghotaslou R, Naghili B, Hasani A, Aghazadeh M, et al. Molecular screening of virulence genes in high-level gentamicin-resistant Enterococcus faecalis and Enterococcus faecium isolated from clinical specimens in Northwest Iran. Indian J Med Microbiol 2012;30(2):175-81.

18. Komiyama EY, Lepesqueur LS, Yassuda CG, Samaranayake LP, Parahitiyawa NB, Balducci I, et al. Enterococcus species in the oral cavity: prevalence, virulence factors and antimicrobial susceptibility. PloS One 2016;11(9):e0163001.

19. Soares RO, Fedi AC, Reiter KC, Caierao J, d'Azevedo PA. Correlation between biofilm formation and gelE, esp, and agg genes in Enterococcus spp. clinical isolates. Virulence 2014;5(5):634-7.

20. Almohamad S, Somarajan SR, Singh KV, Nallapareddy SR, Murray BE. Influence of isolate origin and presence of various genes on biofilm formation by Enterococcus faecium. FEMS Microbiol Lett 2014;353 (2):151-6.

21. Al-Talip H, Zuraina N, Kamarudin B, Yean CY. Genotypic variations of virulent genes in Enterococcus faecium and Enterococcus faecalis isolated from three hospitals in Malaysia. Adv Clin Exp Med 2015;24(1):121-7.

22. Saba Çopur Ş, Şahin F, Göçmen JS. Determination of virulence and multidrug resistance genes with polymerase chain reaction method in vancomycin-sensitive and -resistant enterococci isolated from clinical samples. Turk J Med Sci 2016;46(3):877-91.

23. Heidari $H$, Emaneini $M$, Dabiri $H$, Jabalameli F. Virulence factors, antimicrobial resistance pattern and molecular analysis of enterococcal strains isolated from burn patients. Microb Pathog 2016;90:93-7.

24. Arabestani MR, Nasaj M, Mousavi SM. Correlation between infective factors and antibiotic resistance in enterococci clinical isolates in West of Iran. Chonnam Med J 2017;53(1):56-63.

25. Sillanpaa J, Prakash VP, Nallapareddy SR, Murray BE. Distribution of genes encoding MSCRAMMs and pilli in clinical and natural populations of Enterococcus faecium. J Clin Microbiol 2009;47(4):896-901.

26. Sallem RB, Klibi N, Klibi A, Ben Said I, Dziri R, Boudabous A, et al. Antibiotic resistance and virulence of enterococci isolates from healthy humans in Tunisia. Ann Microbiol 2016;66(2):717-25.

27. Xu W, Flores-Mireles AL, Cusumano ZT, Takagi E, Hultgren SJ, Caparon MG. Host and bacterial proteases influence biofilm formation and virulence in a murine model of enterococcal catheter-associated urinary tract infection. NPJ Biofilms Microbiomes 2017;3:28.

28. Golinska E, Tomusiak A, Gosiewski T, Wiecek G, Machul A, Mikolajczyk D, et al. Virulence factors of Enterococcus strains isolated from patients with inflammatory bowel disease. World J Gastroenterol 2013;19(23):3562-72. 